\title{
Duodenum and Ampulla of Vater Neuroendocrine Tumor cMO TNM Finding v8
}

National Cancer Institute

\section{Source}

National Cancer Institute. Duodenum and Ampulla of Vater Neuroendocrine Tumor cMO

TNM Finding v8. NCI Thesaurus. Code C135053.

Duodenum and ampulla of Vater neuroendocrine tumor without evidence of distant

metastasis. (from AJCC 8th Ed.) 